p-ISSN: $2338-4794$

e-ISSN: 2579-7476

Vol.8. No. 1 Januari-April 2020

\title{
PENGARUH KUALITAS PRODUK DAN HARGA TERHADAP KEPUTUSAN PEMBELIAN PELANGGAN RUANGOPI GALAXY KOTA BEKASI
}

\author{
Reina Athira ${ }^{1)}$ \\ 1) Mahasiswa Program Studi Manajemen FE UNKRIS \\ E-mail: rachmarwi@gmail.com \\ Wiwik Rachmarwi ${ }^{2)}$ \\ 2) Dosen Program Studi Manajemen FE UNKRIS \\ Alamat: Kampus UNKRIS, Jatiwaringin Jakarta Timur \\ E-mail: rachmarwi@gmail.com, wiwikrachmarwi@unkris.ac.id

\begin{abstract}
This study aims to determine the effect of purchasing decisions by consumers on product quality and prices on coffee products in Ruangopi. This research is quantitative descriptive. Type of the research was descriptive verification that with the depiction and exposure variables studied and then pulled conclusion. Research variable which being independent variable was a product quality and the price as well as the purchasing decisions as the dependent variable. The population in this study were consumers who came to Ruangopi for 1 month. Sampling in this study using random sampling to 83 consumers who buy coffee in Ruangopi. Test instruments conducted with validity test and reliability test and analysis techniques used were multiple regression analysis.
\end{abstract}

Keywords: Kualitas produk, harga dan keputusan pembelian

\section{PENDAHULUAN}

Seiring berjalannya waktu dan majunya peradaban dan budaya serta berkembangnya arus globalisasi menimbulkan adanya pergeseran budaya dari masyarakat sosial yang lebih cenderung menjadi masyarakat yang lebih konsumtif dan lebih memilih berkumpul bersama orang-orang terdekat diluar rumah dibandingkan di rumah. Konsumen menuntut suatu produk yang sesuai dengan selera, kebutuhan dan daya beli mereka.Hal ini menyebabkan perusahaan-perusahaan mengalami persaingan yang begitu ketat karena tuntutan keinginan konsumen yang semakin kompleks.

Di Indonesia sendiri sudah semakin banyak penikmat kopi dan pecinta kopi dimana penikmat kopi ini memilih kedai kopi atau bahasa populernya adalah coffeeshop yang nyaman sebagai tempat berkumpul maupun melakukan kegiatan bisnis. Tetapi banyak pula yang benarbenar memperhatikan kualitas kopi tersebut dari biji kopi yang di olah menjadi kopi yang sudah siap di minum.

Semakin berkembangnya bisnis ini, maka semakin membuat para pelaku bisnis ini berlomba-lomba mendapatkan produk-produk yang tidak kalah saing dengan para pelaku bisnis lainnya. Kondisi pasar yang kompetitif dan dinamis membuat para pelaku bisnis harus bisa mengamati persaingan dalam lingkungan bisnisnya. Dalam menghadapi lingkungan bisnis yang semakin ketat, perusahaan harus bisa mengendalikan situasi tersebut dengan meningkatkan sumber daya manusia dan sumber daya ekonominya guna meningkatkan daya saing pasar, serta perusahaan dituntut untuk bisa membuat 
serangkaian strategi pemasaran yang efektif dan selalu mengembangkannya. Hal ini dilakukan guna meraih keunggulan kompetitif terhadap perusahaan lainnya.

Dalam upaya mendatangkan pelanggan-pelanggan baru dan mempertahankan pelanggan terdahulu yaitu menumbuhkan minat beli.Banyak faktor yang mempengaruhi dalam keputusan pembelian.Baik dari faktor internal dalam diri konsumen ataupun pengaruh eksternal.Yang dimana pelaku usaha harus mampu mengidentidikasi perilaku konsumen dalam hubungannya melakukan suatu keputusan pembelian.

Ruangopi berusaha menawarkan produk Seperti halnya coffeeshop kebanyakan dengan menetapkan standarstandar operasional untuk mendapatkan dan mempertahankan kualitas produknya.Diantaranya adalah jenis bahan yang digunakan untuk menu unggulan kedai kopi ini adalah kopi espresso yang mempunyai ukuran kopi Arabica sebesar $90 \%$ dan robusta $10 \%$. Kedai kopi menetapkan standar pembuatan espresso untuk setiap satu shoot espresso selama 25 detik.

Kualitas memiliki arti yang penting dalam keputusan pembelian. Jika kualitas produk yang dihasilkan baik maka konsumen biasanya akan melakukan pembelian ulang. Tetapi jika kualitas produk tidak sesuai dengan harapan, maka konsumen akan mengalihkan pembeliannya pada tempat lain yang menjual jenis produk yang sama. Kualitas memang konsep terpenting dalam menciptakan suatu produk. Sebuah produk yang berkualitas adalah produk yang diterima oleh konsumen sesuai dengan kebutuhan dan keinginan pelanggan. Ruangopi juga ingin memenuhi keinginan dan kebutuhan konsumen yang ingin menikmati kopi dengan nikmat, nyaman dan santai dengan harga yang terjangkau yang menyediakan kopi yang berkualitas dan beragam dengan harga yang kompetitif serta adanya hidangan pendamping yang mendukung dengan harga berkisar antara Rp. 15.000 s/d Rp. 35.000. Dengan begitu, masyarakat lebih cenderung menyukai tempat yang mengasyikan untuk berkumpul dengan harga kopi yang tidak terlalu mahal pula.

\section{LANDASAN TEORI}

\section{Keputusan Pembelian}

Menurut Kotler dan Armstrong (2008), keputusan pembelian konsumen adalah membeli merek yang paling diskuai dari berbagai alternatif yang ada, tetapi dua faktor bisa berada antara niat pembelian dan keputusan pembelian. Faktor pertama adalah sikap orang lain dan faktor yang kedua adalah faktor situasional. Oleh karena itu, preferensi dan niat pembelian tidak selalu menghasilkan pembelian yang aktual. Sedangkan menurut Setiadi (2010) keputusan konsumen untuk membeli suatu produk selalu melibatkan aktivitas secara fisik (berupa kegiatan langsung konsumen melalui tahapan-tahapan proses pengambilan keputusan pembelian) dan aktivitas secara mental (yakni saat konsumen menilai produk sesuai dengan kriteria tertentu yang ditetapkan oleh individu). Menurut Kuncoro dan Aditya (2010) keputusan pembelian adalah suatu keputusan sebagai pemilihan suatu tindakan dari dua atau lebih pilihan alternseatif. Seorang konsumen yang hendak melakukan pilihan maka ia harus memiliki pilihan alternatif. Dengan demikian, ia harus mengambil keputusan merek. Sementara menurut Schiffman dan Kanuk (2007) keputusan pembelian adalah seleksi terhadap dua pilihan atau lebih. Dengan perkataan lain, pilihan alternatif harus tersedia bagi seseorang ketika pengambilan keputusan. Setiap konsumen melakukan berbagai macam keputusan tentang pencarian, pembelian, 
penggunaan beragam produk dan merek pada setiap periode tertentu.

Menurut Philip Kotler (2003) konsumen melewati lima tahapan dalam proses keputusan pembelian yang sebenarnya proses tersebut telah dimulai jauh sebelum pembelian aktual terjadi dan sudah memiliki konsekuensi setelah pembelian terjadi. Lima faktor internal yang relevan dalam proses pembuatan keputusan pembelian, yaitu : a). Motivasi yang merupakan sebuah dorongan yang ada dalam diri manusia itu sendiri untuk mencapai suatu tujuan tertentu yang sudah ia rencanakan sebelumnya. b). Persepsi yang merupakan hasil evaluasi seseorang terhadap kejadian yang diterimanya berdasarkan informasiinformasi serta pengalaman yang sudah pernah ia lalui. c). Pembentukan sikap merupakan sebuah penilaian yang ada di diri seseorang yang dapat mencerminkan sikap suka maupun tidak suka terhadap sesuatu hal. d). Integrasi merupakan sebuah kesatuan antara sikap dan tindakan yang merupakan suatu respon atas sikap yang diambil olehnya. e). Perasaan suka akan mendorong seseoranguntuk kembali membeli dan perasaan tidak suka akan mendorong seseorang untuk tidak kembali membeli produk tersebut.

Menurut Kotler dan Keller (2007) faktor-faktor yang mempengaruhi konsumen dalam pengambilan keputusan pembelian, yaitu : a). Faktor kebudayaan; Budaya adalah kumpulan nilai dasar atau presepsi atau keinginan dan perilaku yang dipelajari oleh anggota masyarakat dari keluarga. b). Faktor sosial; Kelompok merupakan suatu kumpulan yang terdiri dari dua orang atau lebih yang akan berinteraksi untuk mencapai tujuan pribadi atau tujuan bersama. c). Faktor pribadi; Usia dan tahap siklus hidup yang merupakan bentuk siklus kehidupan keluarga mengenai tahap-tahap yang mungkin dilalui keluarga sesuai kedewasaannya. Baik dari usia muda, pertengahan maupun usia tua. d). Faktor psikologis; Motivasi merupakan tekanan kuat yang mendorong seseorang untuk mencari kepuasan atas kebutuhan tersebut.

\section{Kualitas Produk}

Perusahaan perlu mengadakan pengendalian mutu untuk mengetahui sampai sejauh mana proses dan hasil produk yang dibuat sesuai dengan standar yang ditetapkan perusahaan. Hal ini sesuai dengan pendapat Prawirosentono. Menurutnya pengendalian mutu tersebut diantaranya adalah: a). Pengendalian mutu bahan. Mutu bahan akan sangat mempengaruhi hasil akhir barang yang akan dibuat. Bahan baku yang baik akan menghasilkan barang yang baik. Pengendalian mutu bahan harus dilakukan sejak penerimaan bahan baku, penyimpanan dan waktu bahan baku diproses produksi. b). Pengendalian mutu dalam proses pengolahan. Diadakan pengawasan terhadap seluruh proses produksi dari awal hingga akhir. Disini perlu adanya kerja saling mendukung antara karyawan satu dengan yang lainnya termasuk pihak manajemen. c). Pengendalian mutu produk akhir. Produk akhir harus diawasi mutunya sejak keluar dari proses produksi hingga sampai pada konsumen. Dalam memasarkan produk perusahaan harus berusaha menampilkan produk yang bermutu. Hal ini hanya dapat dilaksanakan bila atas produk akhir tersebut dilakukan pengecekan mutu agar produk tidak sampai ke tangan konsumen. (Prawirosetomo, 2002)

Kualitas produk adalah kemampuan suatu barang untuk memberikan hasil atau kinerja yang sesuai atau melebihi dari apa yang diinginkan pelanggan menurut Kottler (2003). American Society of Quality Control (Kotler dan Keller, 2008), mendifinisikn bahwa mutu sebagai keseluruhan fitur dan sifat produk atau pelayanan yang berpengaruh pada kemampuannya untuk memuaskan 
kebutuhan yang dinyatakan atau yang tersirat. Maka dari itu setiap kegiatan pemasaran seperti riset pemasaran, pelatihan-pelatihan penjualan, periklanan dan pelayanan pelanggan dan sebagainya dilakukan dengan standar yang tinggi. Secara konvensional kualitas menggambarkan karakteristik langsung dari suatu produk seperti performa, keandalan, mudah dalam penggunaan dan estetika. Sedangkan secara strategik kualitas adalah sesuatu yang mampu memenuhi kebutuhan atau keinginan pelanggannya (Saputro, 2010)

Menurut Kottler (2011), kualitas produk adalah keseluruhan ciri serta dari suatu produk atau pelayanan pada kemampuan untuk memuaskan kebutuhan yang dinyatakan atau tersirat. Sedangkan Lupiyoadi (2013) menyatakan bahwa konsumen akan merasa puas bila hasil evaluasi mereka menunjukkan bahwa produk yang mereka gunakan berkualitas. Menurut Orville, et al, dalam Lupiyoadi (2013) apabila perusahaan ingin mempertahankan keunggulan kompetitifnya dalam pasar, perusahaan harus mengerti aspek dimensi apa saja yang digunakan oleh konsumen untuk membedakan produk yang dijual perusahaan tersebut dengan produk pesaing. Menurut Orville, et al, dalam Lupiyoadi (2013).

\section{Harga}

Menurut Kottler dan Armstrong (2013), Sejumlah uang yang dibebankan atas suatu barang atau jasa atau jumlah dari nilai uang yang ditukar konsumen atas manfaat - manfaat karena memiliki atau menggunakan produk atau jasa tersebut. Penetapan harga yang tepat adalah merupakan bagian strategi dalam manajemen pemasaran. Kesalahan menetapkan harga akan berpentgaruh pada persepsi konsumen terhadap produk. Apabila harga produk terlau mahal maka produk atau jasa yang bersangkutan tidak akan terjangkau oleh konsumen, sehingga nilanya akan rendah. Sebaliknya, jika harga terlampau rendah perusahaan akan sulit mendapatkan laba atau sebagian konsumen akan memiliki persepsi akan kualitas produk yang dipasarkan itu murahan.

Harga merupakan unsur bauran pemasaran yang mendatangkan pendapatan bagi perusahaan. Dari sudut pandang pemasaran, harga merupakan satuan moneter atau ukuran lainnya (termasuk barang dan jasa lainnya) yang dibutuhkan agar memperoleh hak kepemilikan atau penggunaan suatu barang atau jasa (Tjiptono, 2015). Harga merupakan indikator nilai yang digunakan konsumen untuk menentukan pilihan pembelian bilamana harga tersebut akan dihubungkan dengan manfaat yang dirasakan atas barang atau jasa.

Menurut Staton (2004) ada beberapa faktor yang mempengaruhi penetapan harga suatu produk, yaitu : 1). Permintaan produk; Ada baiknya dalam menjalankan usaha, memperkitakan permintaan total produk adalah langkah yang cukup penting dalam penetapan harga sebuah produk. 2). Target pangsa pasar; Pangsa pasar dipengaruhi oleh kapasitas produksi perusahaan dan kemudahan untuk masuk dalam sebuah persaingan pasar yang ada. 3). Reaksi pesaing; 4). Tidak bisa dipungkiri bahwa persaingan ketat pasti akan terjadi di dunia bisnis. Maka dari itu persaingan yang baik akan sangat berpengaruh untuk menetapkan harga. 5). Penggunaan strategi penetapan harga; Untuk produk baru biasnanya menggunakan strategi penetapan saringan. Strategi ini berupa penetapan harga yang tinggi dalam lingkup harga yang diharapkan konsumen. 6). Produk, saluran distribusi dan promosi; Untuk beberapa jenis produk biasanya konsumen lebih memilih produk yang memiliki harga yang murah dan memiliki kualitas yang bagus. 7). Biaya produksi; Harga sering kali 
digunakan sebagai indikator nilai yang dimana harga tersebut menguhubungkan manfaat yang dirasakan baik dari jasa maupun produk tersebut.

\section{METODE PENELITIAN}

Penelitian ini menggunakan pendekatan penelitian kuantitatif dimana variabel penelitian yang digunakan adalah kualitas produk $\left(\mathrm{X}_{1}\right)$, harga $\left(\mathrm{X}_{2}\right)$ dan keputusan pembelian (Y). Metode pengumpulan data yang digunakan adalah dengan menggunakan kuesioner, yaitu dengan memberikan daftar pertanyaan kepada responden dan sampel dalam penelitian ini adalah 83 responden dengan menggunakan skala likert. Dalam penelitian ini teknik sampling yang digunakan yaitu accident sampling di Ruangopi Galaxy, Kota Bekasi dalam ukuran 1 bulan ditemui pelanggan. Metode analisis data dilakukan dengan regresi berganda yang sebelumnya sudah dilakukan uji validitas dan realiabilitas.

\section{HASIL PENELITIAN DAN PEMBAHASAN}

\section{Hasil Penelitian Uji Validitas}

Dari 11 butir pernyataan variabel kualitas produk, menunjukkan bahwa $\mathrm{r}$ hitung sebesar $0.634 \mathrm{~s} / \mathrm{d} 0.756>$ r-tabel sebesar 0.215, sedangkan dari 6 butir pernyataan variabel harga menunjukkan bahwa r-hitung sebesar $0.622 \mathrm{~s} / \mathrm{d} 0.760$ > r-tabel 0.215. Dari 8 butir pernyataan keputusan pembelian menunjukkan bahwa r-hitung sebesar $0.650 \mathrm{~s} / \mathrm{d} 0.793$ > $r$ t-tabel 0.215. Berarti berdasarkan hasil uji validitas menunjukkan bahwa kualitas produk, harga dan keputusan pembelian adalah valid.

\section{Uji Reliabilitas}

Dari hasil uji Reliabilitas diperoleh hasil sebagai berikut:

Tabel 1. Hasil Uji Reliabilitas

\begin{tabular}{lccc}
\hline \multicolumn{1}{c}{ Variabel } & $\begin{array}{c}\text { Cronbach } \\
\text { Alpha }\end{array}$ & $\begin{array}{c}\text { Nilai } \\
\text { Kritis }\end{array}$ & Ket. \\
\hline Kualitas Produk & 0,898 & 0,6 & Reliabel \\
Harga & 0,790 & 0,6 & Reliabel \\
Keputusan Pembelian & 0,863 & 0,6 & Reliabel \\
\hline
\end{tabular}

Berdasarkan Tabel 1, nilai reliabilitas cronbach alpha tersebut tampak bahwa seluruh semua variabel membentuk ukuran yang reliabel, baik dari variabel kualitas produk, harga dan keputusan pembelian

Tabel 2: Pengaruh Kualitas Prosuk Terhadap Keputusan Pembelian

\begin{tabular}{lccccc}
\hline \multirow{2}{*}{ Variabel } & R Square & Konstanta & $\begin{array}{c}\text { Koefisien } \\
\text { Regresi }\end{array}$ & Sig. & $\boldsymbol{\alpha}$ \\
\cline { 2 - 6 } & 0.830 & 2.550 & 0.680 & 0.000 & 0.05 \\
\hline Kualitas Produk & 0.070 & & \\
\hline Pengujian Signifikansi & & & \\
\hline t hitung $>$ t tabel $=19.871>1.664$ \\
\hline
\end{tabular}

Keterangan : Variabel Keputusan Pembelian

Sumber: data diolah 2019 
Berdasarkan Tabel 2, Nilai $R$ square adalah sebesar 0,830 atau 83,0\%, artinya bahwa kualitas produk memberikan kontribusi kepada keputusan pembelian pelanggan Ruanggopi Galaxy Kota Bekasi adalah sebesar 83,0\%, sedangkan sisanya sebesar $17,0 \%$ disumbangkan oleh variabel lainnya yang tidak diteliti, seperti harga. Berdasarkan hasil perhitungan koefisien regresi secara parsial diperoleh persamaan regresi yaitu sebesar $\mathrm{Y}=2,550+0,680\left(\mathrm{X}_{1}\right)$. Koefisien kualitas produk adalah sebesar 0,680. Artinya setiap peningkatan kualitas produk satu kali, maka keputusan pembelian pelanggan Ruanggopi Galaxy Kota Bekasi akan meningkat sebesar 0,680 kali.

Pengujian secara parsial kualitas produk terhadap keputusan pembelian pelanggan dilakukan dengan membandingkan t hitung dan t tabel atau dengan tingkat Signifikansi prob. $=0.000$ untuk $\alpha=0.05$. Berdasarkan perhitungan Tabel 2, dapat dilihat bahwa nilai t hitung $=19,871>\mathrm{t}$ tabel 1,664, maka dapat diartikan terdapat pengaruh yang positif dan signifikan kualitas produk terhadap keputusan pembelian pelanggan Ruanggopi Galaxy Kota Bekasi.

Tabel 3: Pengaruh Harga Terhadap Keputusan Pembelian

\begin{tabular}{lccccc}
\hline \multirow{2}{*}{ Variabel } & \multicolumn{5}{c}{ Parameter } \\
\cline { 2 - 6 } & R Square & Konstanta & $\begin{array}{c}\text { Koefisien } \\
\text { Regresi }\end{array}$ & Sig. & $\boldsymbol{\alpha}$ \\
\hline Harga & 0.524 & 8.514 & 0.993 & 0.000 & 0.05 \\
\hline
\end{tabular}

Pengujian Signifikansi

$\mathrm{t}$ hitung $>\mathrm{t}$ tabel $=9.441>1.664$

Keterangan : Variabel Keputusan Pembelian

Sumber: data diolah 2019

Berdasarkan Tabel 3, Nilai R square adalah sebesar 0,524 atau 52,4\%, artinya bahwa harga memberikan kontribusi kepada keputusan pembelian pelanggan Ruanggopi Galaxy Kota Bekasi adalah sebesar 52,4\%, sedangkan sisanya sebesar $47,6 \%$ disumbangkan oleh variabel lainnya yang tidak diteliti, seperti kiualitas produk. Berdasarkan hasil perhitungan koefisien regresi secara parsial diperoleh persamaan regresi yaitu sebesar $\mathrm{Y}=8,514+0,993\left(\mathrm{X}_{1}\right)$. Koefisien harga adalah sebesar 0,993. Artinya setiap peningkatan harga satu kali, maka keputusan pembelian pelanggan Ruanggopi Galaxy Kota Bekasi akan meningkat sebesar 0,993 kali.

Pengujian secara parsial harga terhadap keputusan pembelian pelanggan dilakukan dengan membandingkan $t$ hitung dan $\mathrm{t}$ tabel atau dengan tingkat Signifikansi prob. $=0.000$ untuk $\alpha=$ 0.05 . Berdasarkan perhitungan Tabel 2, dapat dilihat bahwa nilai t hitung $=9,441$ $>\mathrm{t}$ tabel 1,664, maka dapat diartikan terdapat pengaruh yang positif dan signifikan harga terhadap keputusan pembelian pelanggan Ruanggopi Galaxy Kota Bekasi.

Tabel 4: Pengaruh Kualitas Produk dan Harga Terhadap Keputusan Pembelian

\begin{tabular}{lccccc}
\hline \multirow{1}{*}{ Variabel } & R Square & Konstanta & $\begin{array}{c}\text { Koefisien } \\
\text { Regresi }\end{array}$ & Sig. & $\boldsymbol{\alpha}$ \\
\cline { 2 - 6 } $\begin{array}{lccc}\text { Kualitas Produk } \\
\text { Harga }\end{array}$ & 0.841 & 0.968 & $\begin{array}{c}0.599 \\
0.208\end{array}$ & 0.000 & 0.05 \\
\hline
\end{tabular}

Pengujian Signifikansi

F hitung $>$ F tabel $=217.763>3.110$ 
Keterangan : Variabel Keputusan Pembelian Sumber: data diolah 2019

Berdasarkan Tabel 4, nilai $\mathrm{F}$ hitung $217.763>\mathrm{F}$ tabel 3.110, dan nilai signifikan sebesar $0.000<0.05$ dalam arti kualitas produk dan harga berpengaruh signifikan terhadap keputusan pembelian pelanggan Ruanggopi Galaxy Kota Bekasi. Nilai $\mathrm{R}$ square adalah sebesar 0,841 atau $84,1 \%$, artinya kualitas produk dan harga kerja memberikan kontribusi kepada keputusan pembelian pelanggan Ruanggopi Galaxy Kota Bekasi adalah sebesar 84,1\%, sedangkan sisanya sebesar $15,9 \%$ disumbangkan oleh variabel lainnya yang tidak diteliti.

Berdasarkan hasil perhitungan koefisien regresi secara simultan diperoleh persamaan regresi yaitu sebesar $\mathrm{Y}=0,968+0,599\left(\mathrm{X}_{1}\right)+0,208\left(\mathrm{X}_{2}\right)$. Koefisien kualitas produk adalah sebesar 0,599, artinya setiap peningkatan kualits produk satu kali, maka keputusan pembelian pelanggan Ruanggopi Galaxy Kota Bekasi akan meningkat sebesar 0,599 kali, dengan asumsi harga tetap. Koefisien harga adalah sebesar 0,208, artinya setiap peningkatan harga satu kali, maka keputusan pembelian pelanggan Ruanggopi Galaxy Kota Bekasi akan meningkat sebesar 0,209 kali, dengan asumsi kualitas produk tetap.

\section{Pembahasan}

Pengaruh Kualitas Produk Terhadap Keputusan Pembelian Pelanggan

Berdasarkan hasil yang telah dilakukan bahwa kualitas produk berpengaruh signifikan terhadap keputusan pembelian pelanggan Ruangopi Galaxy Kota Bekasi, dalam arti lain hipotesis Ho ditolak $\mathrm{Ha}$ diterima. Artinya bahwa kualitas produk berpengaruh terhadap keputusan pembelian pelanggan Ruangopi Galaxy Kota Bekasi. Hasil penelitian ini mempunyai hasil yang sama dengan penelitian terdahulu yang dilakukan oleh
Muhammad Fauzi Hasibuan (2017) bahwa kualitas produk berpengaruh positif terhadap keputusan pembelian buket bunga di Mandiri Florist Medan.

\section{Pengaruh Harga Terhadap Keputusan Pembelian Pelanggan}

Berdasarkan hasil yang telah dilakukan bahwa harga berpengaruh signifikan terhadap keputusan pembelian pelanggan Ruangopi Galaxy Kota Bekasi, dalam arti lain hipotesis Ho ditolak $\mathrm{Ha}$ diterima. Artinya bahwa harga berpengaruh positif terhadap keputusan pembelian pelanggan Ruangopi Galaxy Kota Bekasi. Hasil penelitian ini mempunyai hasil yang sama dengan penelitian terdahulu yang dilakukan oleh Gerry Doni Ratela (2016) bahwa harga berpengaruh positif dan signifikan terhadap keputusan pembelian pada Ruangopi.

\section{Pengaruh Kualitas Produk dan Harga Terhadap Keputusan Pembelian Pelanaggan}

Berdasarkan hasil uji yang telah dilakukan bahwa variabel kualitas produk dan harga berpengaruh signifikan terhadap keputusan pembelian pelanggan Ruangopi Galaxy Kota Bekasi, dalam arti lain hipotesis Ho ditolak $\mathrm{Ha}$ diterima. Artinya bahwa kualitas produk dan harga berpengaruh terhadap keputusan pembelian pelanggan Ruangopi Galaxy Kota Bekasi. Hasil penelitian ini mempunyai hasil yang sama dengan penelitian terdahulu yang dilakukan oleh Baruna Hadi Brata (2017) bahwa kualitas produk, harga, promosi dan lokasi mempengaruhi keputusan pembelian secara bersama-sama.

KESIMPULAN DAN SARAN

\section{Kesimpulam}


Hasil penelitian menunjukkan bahwa 1). Kualitas produk mendorong keputusan pembelian pelanggan Ruangopi Galaxy Kota Bekasi. 2). Harga mendorong keputusan pembelian pelanggan Ruangopi Galaxy Kota Bekasi. 3). Kualitas produk dan harga mendorong secara bersama-sama keputusan pembelian pelanggan Ruangopi Galaxy Kota Bekasi.

\section{Saran}

Adapun saran-saran adalah sebagai berikut: 1). Hasil perhitungan kualitas produk merupakan variabel yang paling berpengaruh terhadap keputusan pembelian. Maka Ruangopi harus tetap menjaga kualitas produk nya untuk meningkatkan pembelian konsumen. Indikator estetika adalah indikator paling tinggi dari konsumen, untuk itu Ruangopi harus tetap menjaga signature kopi setiap kopi yang disuguhinya. Dan indikator keandalah paling rendah dari konsumen untuk itu Ruangopi harus mengevaluasi biji-biji kopi yang akan dibeli memiliki kualitas yang baik dibandingkan dengan biji kopi yang sebelumnya. 2). Hasil perhitungan harga merupakan variabel yang berpengaruh kedua terhadap keputusan pembelian. Indikator keterjangkauan harga dan kesesuaian harga dengan kualitas produk memiliki tanggapan paling tinggi dan indikator daya saing harga memiliki tanggapan paling rendah dari konsumen, untuk itu Ruangopi perlu mengevaluasi dan melihat apakah harga yang ditawarkan cukup bersaing atau tidak.

\section{DAFTAR PUSTAKA}

Buchari, Alma. 2011. Manajemen Pemasaran dan Pemasaran Jasa. Bandung : Alfabeta.

Darmawi, Herman. 2011. Manejemen Perbankan. Jakarta: PT Bumi Aksara.
Ghozali, Imam. 2011. Aplikasi Analisis Multivariate dengan Program IBM SPSS19. Semarang: Badan Penerbit Universitas Diponegoro.

Husein, Umar. 2002. Metode Riset Bisnis. Jakarta: PT Gramedia

Isyanto, Puji. 2012. Pengaruh Kualitas Produk terhadap Keputusan Pembelian Handphone Blackberry pada Mahasiswa Ekonomi Universitas Singaperbangsa Karawang. Jurnal Manajemen Vol.09 No.4 Juli 2012: 854-862.

Kotler, Philip and Amstrong, Gary. 2012. Priciples of Marketing Global. 14thedition. New Jersey: Prentice.

Kotler, Philip and Keller, Kevin Lane. 2012. Marketing Management. 14th edition. New Jersey: Prentice.

Malhotra, Naresh K. 2009. Riset Pemasaran Pendekatan Terapan. Jilid 1. Jakarta: PT Index.

Purwati.2012. Pengaruh Harga dan Kualitas Produk terhadap Keputusan Pembelian Motor Honda Matic Beat (Studi Kasus Pada PT. Nusantara Solar Sakti).Vol 2, No. 3. September 2012 : 260-277.

Santoso, Singgih. 2002. Statistik Parametrik. Jakarta: PT Gramedia. Pustaka Utama.

Sanusi, Anwar. 2011. Metedologi Penelitian Bisnis. Jakarta Selatan: Salemba Empat

Sugiyono. 2011. Metode Penelitian Kuantitatif, Kualitatif dan $R \& D$. Bandung: Alfabeta.

Tjiptono, Fandy .2008. Strategi Bisnis Pemasaran. Yogyakarta: Andi. 68

Wangean, Ryanto Hariandy. 2014. Analisis Citra Merek, Kualitas Produk dan Harga Pengaruhnya terhadap Keputusan Pembelian Konsumen Pada Mobil All New Kia Rio di Kota Manado. Vol.2 No.3 September 2014, Hal. 17151725.

Weenas, Jackson R. S. 2013. Kualitas Produk, Harga, Promosi, dan 
Kualitas Pelayanan Pengaruhnya

Terhadap Keputusan Pembelian

Spring Bed Comforta. Vol. 1, No. 4,

Desember 2013 : 607-618 